\title{
Factors Influencing the Effectiveness of the Competition Based Learning (CBL) Activity among Accounting Undergraduates
}

\author{
Corina Joseph ${ }^{\mathrm{a}}$, Mariam Rahmat ${ }^{\mathrm{b}}$ \\ ${ }^{a}$ Faculty of Accountancy, Universiti Teknologi MARA, Cawangan Sarawak, \\ 94300 Kota Samarahan, Sarawak, Malaysia \\ corina@uitm.edu.my \\ ${ }^{b}$ Faculty of Accountancy, Universiti Teknologi MARA, Cawangan Sarawak, \\ 94300 Kota Samarahan, Sarawak, Malaysia \\ mariamr@uitm.edu.my
}

DOI: https://doi.org/10.37134/ibej.vol12.1.2019

\begin{abstract}
Teaching an entirely reading topic to accounting students in higher education is sometimes challenging as students generally prefer calculation topics. Teaching a purely reading topic is a challenge to the lecturer and the students may face problems in digesting the topic taught. Therefore, the engagement in learning is essential to enhance the understanding on the subject matter among students. Educators use a competition-based learning model to bring students' deficiencies under control in their learning process in higher education. A specific learning activity involving the model was carried out through the production of mind mapping video for the course of Advanced Financial Accounting and Reporting 2 on the Corporate Social Responsibility topic. The study was conducted to examine the factors influencing the effectiveness of the Competition-Based Learning activity in the accounting course. A questionnaire was particularly developed and distributed to all 63 students from the Bachelor of Accountancy Program, Universiti Teknologi MARA, Sarawak Branch, who went through the course in Semester March-July 2018. From the survey, the mind mapping video competition was effective for teaching and learning as the respondents and participants had agreed in general. However, factors, such as number of times taking the course, number of family members in higher education, parents' level of academic qualification and MUET results revealed no differences on the effectiveness of the competition-based learning activity in the accounting course. Finally, the Corporate Social Responsibility examination score showed no correlation with the effectiveness of the competition-based learning activity.
\end{abstract}

\section{Keywords:}

Competition-based learning, accounting course, mind mapping

\section{INTRODUCTION}

At present time, complications in educating and teaching resurfacing are definitely inevitable to both educators and students in institutions of higher learning. A clear example that portrays this is the students' lack of self-esteem and motivation in the learning process, which may lead to uncertainties to face challenges in their future profession. On the other hand, educators have to spare all efforts in order to cope with modern technology for teaching purposes as well as to meet the requirements needed to learn and master innovative educating mechanism. Employers are also demanding for multi-talented graduates with great skills. This includes the abilities to establish an outstanding teamwork, solve problems, possess project management skills, and many more. Consequently, students are encouraged to be more attentive during class as student-centred learning has recently become more relevant (Caroll, 2013). In line with market requirements, a study program specifying the Indented 
Learning Outcomes (ILOs) has been designed to "focus on the concept of motivation, selfesteem, problem solving, teamwork, solving real-world problems, competition, and innovation" (Issa et al., 2014, p. 2).

Competition-Based Learning (CBL) is one of the ILOs that is included in a few learning models as stated by Issa et al. (2014). Competition Based Learning involves a team of students in an open-ended assignment with similar problems in which students may face at the workplace. However, on the final completion of the task assigned in the course, the performance is being evaluated as a comparison to other groups. This motive is done to remove the mind set of "completing it just to get it over with" and motivate the students to think of an unpassable overall project (Caroll, 2013, p. 3). Learning relies on the competition results as suggested by the CBL (Johnson et al., 1985). Furthermore, a reward system is implemented when the task assigned is completed (Sukiman et al., 2016). While remaining engaged, students are able to converge with the facility and classmates better in CBL. Students' soft skills can also be improved through CBL, as well as their critical thinking and problem-solving skills (Khairnar, 2015). It can be easily combined with other learning methods, such as problem-based learning (PBL), project-based learning, collaborative-based learning, cooperative learning, and game-based learning (Burguillo, 2010; Sukiman et al., 2016). CBL is mostly conducted in engineering, computer programming and science-based programs as stated by Sukiman et al. (2016). The students have the opportunity to prepare themselves to compete in their future industry from this learning approach (Kristensen et al., 2015). Meanwhile, their learning activities and outcomes can be enhanced as the collaborative-based learning model maximizes the collaboration among students (more than one student or small groups) to encourage them to share knowledge within their common reinforcement (Caroll, 2013).

Therefore, in this paper, we are enhancing the learning process and boosting the level of learning outcomes by using Competition-Based Learning (CBL) (Issa et al. 2014) and determine the factors influencing the effectiveness of this activity. Through CBL, satisfaction is guaranteed, and learning experience can be improved apart from the real exposure to the competition in business. In order to secure their future career, this model is important so that the students become more competitive. In addition, social learning is promoted through CBL via various aspects, which in return, will provide motivation for effective learning (Blazauskas et al., 2012).

Since 2013, the Malaysia Education Blueprint 2015-2025 has been developed by the Ministry, including the local and international academia, leaders and people at large. The input has been gathered from various stakeholders who came up with the end product. The enhancement of quality in teaching and learning that widens accessibility to the public is available in line with the high internet penetration in Malaysia. It is a necessity to transform the education system from "a mass production delivery model to one where technologyenabled innovations could offer more personalised learning experiences to all students" (Ministry of Education Malaysia, n.d.) according to the National e-learning Policy (Dasar ePembelajaran Negara or DePAN). This involves the preparation and sharing of high quality of teaching and learning materials on the online system. Hence, based on CBL activities, this paper proposes that a learning material can be produced with the purpose of sharing and uploading on the university's online learning management system.

Through the preparation of mind mapping videos for the Advanced Financial Accounting and Reporting 2 (FAR660) course on Corporate Social Responsibility (CSR) 
topic, the CBL: e-Mind Mapping Video competition learning activity has been conducted. As it is not included in the syllabus or lesson plan, this learning activity is an extra and innovative teaching and learning approach. The IQRA reading culture, which is introduced by the Faculty of Accountancy, Universiti Teknologi MARA, is intentionally promoted by this learning activity. As students would generally prefer calculation topics, teaching an entirely reading topic to accounting students in higher education is sometimes devastating. Students may face difficulties in digesting the topic taught by the lecturer on a purely reading topic (Fun \& Maskat, 2010). Therefore, to enhance the understanding on the subject matter among students, the engagement in learning is essential.

In this paper, the CBL learning activity is a competition on the creation of a CSR mind mapping video, which requires the winning video to be uploaded on YouTube and iLearn (the e-learning system of Universiti Teknologi MARA). By conducting the CBL: eMind Mapping Video competition activity, the deficiency of accounting students who tend to be less attentive on reading topics may potentially be dealt with successfully. When it comes to reading subjects, students would usually display lack of motivation and low self-esteem. However, they show deep interest when it is related to technology. Thus, a competition is designed using the CBL model (e.g. Johnson et al., 1985; Issa et al., 2014) to combine creativity and technology skills in order to promote reading interest and achieve the Intended Learning Outcomes (ILOs) as specified in the study program (Blazauskas et al., 2012). In addition, through this CBL: e-Mind Mapping Video competition activity, explicit and implicit learning can be achieved (Kristensen et al., 2015). While explicit learning can be achieved from reading the textbook, implicit learning can be obtained from carrying out hand-on activities, such as preparing a mind mapping task and creating a video out of the mind mapping activity.

Based on the above discussions, the research question posed in this paper is: "What are the factors influencing the effectiveness of the CBL learning activity in the accounting course?" The corresponding objective of the paper is to determine the factors that influence the effectiveness of the CBL learning activity in the accounting course. As there is little published research, this paper is significant in examining the effectiveness of the mind mapping video competition in teaching the CSR topic in the accounting course in developing countries. Joseph and Rahmat (2018) examined the perception on using the competitionbased learning winning video as a pedagogical tool in the accounting course. Overall, the respondents and participants agreed that the winning video was effective for learning in the accounting course. This paper extends Joseph and Rahmat's (2018) work by determining the factors influencing the effectiveness of CBL among accounting undergraduates. Section 2 presents the literature review. The methodology is explained in Section 3. Section 4 provides the results and discussions, while Section 5 presents the concluding comments.

\section{LITERATURE REVIEW}

\section{What is Competition-Based Learning (CBL)}

Issa et al. (2014, p3) defined competition as "a contest between individuals or groups to reach a common goal that cannot be shared". It involves the act or process of competing (Merriam Webster's Dictionary) and usually resulting in a victor and a loser (Cantador and Conde, 2016). CBL can be defined as "a constructivist approach to learning in which competition is used as stimulus for the maximization of the ILOs specified in a given course or curriculum, while team members participate in a project under controlled environment" (Issa et al., 2014, 
p.5). The most important aspect of constructivist theory is that educators view the students as 'active learner' in the networked learning environment. The course's ILOs and any other objectives can be successfully satisfied through the application of CBL model. Learning environment facilitates social interaction between a group of learners; for example, learners and teachers. At the same time, learning resources can be allocated over space and time.

The CBL model utilizes the Project-Based Learning (PBL) and competition which takes the benefits of competitions, PBL and network environment, despite the fact that it precludes shortcomings of competitions (Issa et al., 2014). PBL curriculum results in significantly better examination performances as compared to the traditional teaching curriculum (McParland et.al, 2004, Zahid et al, 2016). CBL is essentially project-based learning that still involves teams of students in an open-ended assignment, which is similar to a problem they may encounter in their career but added with elements of competition to other groups in the course (Carroll, 2013).

Components of CBL consist of a course outline based on a specific curriculum, a clear set of ILOs derived from the course syllabus and aligned with the overall ILOs for the curriculum, project requirements and specification, a set of well-defined competition rules, a set of external incentives or a reward system, a socially networked environment, evaluation committees or judges, and assessment method for ILOs ( Issa et al., 2014, p.5).

\section{Past Studies on CBL}

Many studies have been conducted to determine the direct or indirect factors which influence the academic performance of students. Gajghat et al. (2017) reviewed previous research and classified the factors into academic and non-academic, such as pre-schooling background, family background, personal characteristics, college environmental, and learning habits. A few studies found that gender was significantly related to students' academic performance (Zakaria et al., 2011; Garkaz et al., 2011; Zhang et al., 2004). The findings by Abdullah (2011) showed that female students performed better than the male counterparts, but Zakaria et al. (2011) indicated that male students obtained better grades than female students, and environmental factors affected them differently. Among the dependent variables used to predict the students' performance at the university level in the previous research were semester/ cumulative grade point average, success/failure in the university examinations, retention rate, graduation time, and marks obtained in end semester examination (Gajghat et al., 2017). This study includes gender as one of the factors influencing the CBL activity. As well, this paper examines the association between the academic performance, which is measured by the CSR topic marks in the final examination and the mean on the perception of the CBL activity effectiveness.

A study conducted by Cantandor and Conde (2010) found there was a balance between competition and cooperation and competition in an e-learning environment can be beneficial if the goal is clearly set into the learning process with symbolic or little price and conducted in a short period. Competition also has been often associated as a method in improving the effort-based learning and attention (DiMenichi and Tricomi, 2015). Issa et al. (2014) suggested that educators can steadily convert old-fashioned coursework into CBL as part of the initiative to enhance learners' learning experience and boost the outcomes of learning that is in line with the curriculum objectives. DiMenichi and Tricomi (2015) found that competition can improve attention in a physical task but harmful on working and longterm memory. 
In their study, Butler and Kedar (1990) hypothesized that students working on a group task in an inter-team competition would adopt an ability-focused motivational orientation, while those who were not competing would adopt an intrinsic motivational orientation. The results showed that for the groups in the cooperative school, there was a difference in motivational orientation, as reflected in causal attributions, interest, students' communications, work strategy and performance, and they were more likely to adopt a collaborative work strategy. Bedard and Fischer (2017) examined the effect of relative evaluation on academic performance in a classroom setting. They found that there was a large negative competition effect on students who believed that they were relatively low in the distribution ability, whereas there was no competition effect on those who believed their ability was relatively high. Chan and Lam (2008) also suggested that students' self-efficacy might be threatened when they engage in vicarious learning in a competitive classroom.

McParland et al. (2004) found that the PBL curriculum resulted in significantly better examination performance than the traditional teaching curriculum, for multiple choice questions. Competition has been often associated as a method in improving the effort-based learning and attention (DiMenichi and Tricomi, 2015). Experiments conducted to examine the effects of competition on effort showed that in the physical task, the participants demonstrated faster reaction times, which was a previous indicator of increased attention in the competitive environment. However, other experiments conducted to examine the effect of competition on working memory and long-term memory showed that the participants remembered fewer shapes when competing and later recalled less of these shapes during a post-test. This finding suggests that competition can improve attention in a physical task but harmful in our memory task.

The rewards and game techniques are used in examining the effects of emphasizing the competitive environment in a testing situation (Margaret et al., 1972). The results indicated that both games and rewards techniques revealed no important effect on test performance. Ma and Ma (2014) studied the relationship between learning styles (competitive and cooperative) and mathematics performance among middle school students between the USA and three top-performing East Asian countries (i.e. Hong Kong, Japan, and Korea) in the 2003 Programme for International Student Assessment (PISA). It was found that competitive learning had a statistically significant positive relationship with mathematics performance in all four countries while Cagiltay et al (2015) found that when competition environment is created in a serious game, motivation and post-test scores of learners improve significantly.

The student engagement in learning is improved with the effective use of technology (Beeland (n.d.). Revision for final exam would be much easier when supported by video and enable students to remember important points when watched for several times (Whatley \& Ahmad, 2007; Brecht, 2012). In addition, sharing winning video on YouTube by the instructor would motivate the future students to improve the mind mapping and video production technique. Watching the winning video reduce the tendency to memorize the facts and improve the speed on study, which is, the positive outcome of this active learning style (Whatley \& Ahmad, 2007).

In this paper, the CBL learning activity is a competition on the creation of a corporate social responsibility (CSR) mind mapping video, which requires the winning video to be uploaded via YouTube and i-Learn (the e-learning system of Universiti Teknologi MARA). The CBL is a unique learning activity for the accounting program at Universiti Teknologi 
MARA, which is commonly used in science and technology-based programs. Past studies reported that video is used in learning engineering (Chan, 2010) and language.

\section{Factors Influencing the Use of Innovation in Teaching and Learning Tool}

The advance technology revolution has made teaching become more challenging as students nowadays are generally active, visual and sequential learners. Communication opportunities using technologies, such as computers and the internet, have become one of the most important ways to provide learning resources for students to share and obtain information. Generally, in the traditional accounting courses in many universities, lecturers or instructors present the materials with a 3-hour lecture format each week and spend a significant amount of class time discussing theories in passive, abstract, verbal and sequential teaching styles (Carroll, 2013). Therefore, a learner-centered teaching environment has been widely accepted, which allows students to be more interactive during class.

E-Learning is an interactive method which is specifically delivered via the internet, and the use of information and communication technology (ICT) has enabled the access to online learning and teaching resources. Students can communicate with the teachers or other students in the class, in which grading can be done immediately. Chokri (2012) found that even though students have vast experience in the internet technology and its general use, their experience in using the internet for learning is very low, with $59.6 \%$ of them have problems in using ICT for learning.

Teachers play an important role in stimulating the improvement of innovative skills through their manners, behaviors and communication with students (Chan Lin et al., 2006). However, majority of educators point out that creative teaching does not essentially have to involve the technology although it is regarded as an innovative teaching method (Chan Lin et al., 2006). The technology is used as a teaching tool in a classroom and serves as a self-monitoring tool to promote creativity in students. Many teachers still feel unsure and refuse to use the technology in teaching as they need professional development to overcome technical problems in handling the technology effectively. Besides that, personal factors, such as the teachers' belief about teaching on the content of subject matters and their pedagogy, their experience in using technology and interest in trying new things, as well as social factors, such as the attitude of management, reactions of students, parents and support from the community, have affected their willingness to include technology integration (Chan Lin et al., 2006; Veen, 1993) Lastly, in using the technology, teachers are also concerned on how the students should be assessed for their performance.

From the students' point of view, Chokri (2012) concluded that there are three factors influencing students' positive opinion on the use of the e-learning system, namely; the expertise of learners in ICT for learning, the design of the electronic learning process adopted by online teachers, and the adoption of e-learning (the ease in using the features of the elearning platform). The results also show that exposing students to ICT for learning helps students to solve more learning problems and facilitate the technology that supports elearning.

\section{RESEARCH METHODOLOGY}

This study involved a survey method to determine the factors influencing the effectiveness of the CBL activity in the accounting course. i.e. Advanced Financial reporting II (FAR660) focusing on purely reading topic, i.e. corporate social responsibility (CSR) through competition-based learning using 5 -point Likert scale $(1=$ strongly disagree, $2=$ disagree, 3 $=$ neither disagree nor agree, $4=$ agree, and $5=$ strongly agree). A set of questionnaires was 
designed based on the literature and program outcome for the Advanced Financial Reporting II course, in line with the Outcome Based Education System, the Ministry of Higher Education, Malaysia.

The program outcome for FAR660 consists of:

- The competition instills the teamwork among members.

- The competition improves the communication skills among members.

- The competition helps the students to provide, intepret and evaluate financial and non-financial information to help management make economic decisions

- The competition helps the students to think critically in the application of knowledge and suggest possible solutions to accounting issues

- The competition helps to demonstrate behaviour consistent with professional ethics and social responsibility).

- The competition helps to demontrate a commitment to life-long learning and professional development.

The total population for the study consisted of 63 full time accounting students of Universiti Teknologi MARA Sarawak. The questionnaires were distributed to all 63 full-time students who enrolled for the Advanced Financial Reporting II Course, for semester MarchJuly 2018, in line with the approach undertaken by Sukiman et al. (2016). The total number of questions analysed was 62 as one student did not return the questionnaire.

At the end of the semester March-July 2018, marks for the final examination results on the CSR topic for students who enrolled for the Advanced Financial Reporting II Course, for March-July 2018 in a public university were recorded and analysed. This method was conducted to determine the relationship between the effectiveness of CBL activity and students' performance on CSR questions in the final examination. Before the questionnaire distribution took place, the following steps adopted from Joseph and Rahmat (2018) were conducted.

- A briefing on rules and regulations of the competition on the preparation of mind mapping video and its submission in both hard copy and CD form to all students by the lecturers in charge was conducted in class. The rules and regulations are in line with the CBL requirement used in the implementing university, i.e. University of Petra, Jordan. This adds to the validity of methodology used in this paper.

- Announcement about the competition was also conducted through WhatsApp application and i-Learn system.

- The mind mapping activity involves extraction of concepts from the textbook (Jones et al., 2012). Students were required to read Chapters 8 and 9 of Financial Accounting Theory book written by Craig Deegan which relates to CSR.

- Preparation of mind mapping video by students and submission to the lecturers.

- Evaluation of mind mapping video by the lecturers based on content $(30 \%)$, effectiveness (30\%), and creativity (40\%).

- At the end of the activity, presentations of awards and certificates were given to all the winners.

- The winning video was uploaded on YouTube. 
Descriptive statistic was be used to determine on the overall effectiveness on the effectiveness of CBL activity. An inferential statistical test that determines whether there is a statistically significant difference between the means in two unrelated groups is known as the independent t-test, also called the two-sample t-test. A Pearson correlation test was carried out to determine the association between the CSR scores in the final examination and the effectiveness of CBL activity. The data were analyzed using the Social Science Statistical Package (SSPS) Version 24.0.

\section{RESULTS AND DISCUSSIONS}

Table 1 presents the demographic profile of the respondents. Majority of the respondents took the course for the first time $(82.3 \%)$. The female respondents comprised $77.4 \%$. Majority of the respondents live in the urban area (93.9\%). Furthermore, $77.4 \%$ of the respondents have other family members, i.e. siblings, in the same university. Most of the respondents' guardians (53.2\%) acquired SPM and below academic qualification. In terms of MUET score, majority of the respondents $(51.6 \%)$ scored band 3 and below.

Table 1: Demographic profile

\begin{tabular}{lcc}
\hline Variable & Frequency & Percentage (\%) \\
\hline No of times taking the course: & & \\
$\quad$ First time & 51 & 82.3 \\
$\quad$ Deferral & 11 & 17.7 \\
Gender: & 48 & 77.4 \\
$\quad$ Female & 14 & 22.6 \\
$\quad$ Male & & \\
Hometown: & 52 & 93.9 \\
$\quad$ Urban & 10 & 16.1 \\
$\quad$ Rural & & \\
Family members in higher education: & 48 & 77.4 \\
$\quad$ Yes & 14 & 22.6 \\
$\quad$ No & & \\
Qualification of guardians: & 29 & 46.8 \\
$\quad$ Diploma and above & 33 & 53.2 \\
$\quad$ SPM and below & & \\
MUET score: & 32 & 51.6 \\
$\quad$ Band 3 and below & 30 & 48.4 \\
$\quad$ Band 4 and above & &
\end{tabular}

Table 2 reports the respondents' perceptions on the effectiveness of CBL activity. Cronbach Alpha was used to measure internal consistency of all items tested in the survey, which revealed 0.782 . The overall mean for all items was 4.032 (out of 5). A few statements related to the program outcome for FAR660 indicated that more than $50 \%$ of the respondents agreed/ highly agreed; This competition has taught me the value of teamwork (58.1\%), This competition has improved my communication (51.6\%). This competition has developed my problem-solving skills (56.5\%). 'I work together with my group members to prepare the mind map of CSR topic'(59.7\%). 'My group members give full cooperation in this competition' $(75.8 \%)$. 
The results also promoted readiness to participate in CBL $(40.3 \%)$ and encouraged reading (61.3\%). Overall, the findings did not support Chan and Lam (2008) who suggested students' self-efficacy might be threatened when they engage in vicarious learning in a competitive classroom.

Table 2: Perception on the effectiveness of CBL competition

\begin{tabular}{|c|c|c|c|c|c|}
\hline Likert-scale & 1 & 2 & 3 & 4 & 5 \\
\hline & $\%$ & $\%$ & $\%$ & $\%$ & $\%$ \\
\hline $\begin{array}{l}\text { I was informed about the CSR competition-based learning } \\
\text { activity at the beginning of the semester. }\end{array}$ & 0 & 0 & 1.6 & 33.9 & 64.5 \\
\hline $\begin{array}{l}\text { I was informed about the importance of this CSR topic in } \\
\text { the FAR660 final examination. }\end{array}$ & 0 & 0 & 1.6 & 33.9 & 64.5 \\
\hline $\begin{array}{l}\text { I was informed about the weightage of this topic in the } \\
\text { final examination. }\end{array}$ & 0 & 0 & 4.8 & 35.5 & 59.7 \\
\hline $\begin{array}{l}\text { I started reading the materials required for the competition } \\
\text { during the first week of the competition period. }\end{array}$ & 1.6 & 19.4 & 35.5 & 40.3 & 3.2 \\
\hline $\begin{array}{l}\text { I started reading the materials required for the competition } \\
\text { during the final week before the competition period. }\end{array}$ & 1.6 & 25.8 & 17.7 & 48.4 & 6.5 \\
\hline $\begin{array}{l}\text { I have prepared a schedule in completing the task for this } \\
\text { competition. }\end{array}$ & 0 & 16.1 & 40.3 & 40.3 & 3.3 \\
\hline $\begin{array}{l}\text { I worked together with my group members to prepare for } \\
\text { the mind map of the CSR topic. }\end{array}$ & 0 & 0 & 0 & 40.3 & 59.7 \\
\hline $\begin{array}{l}\text { My group members gave their full cooperation in this } \\
\text { competition. }\end{array}$ & 0 & 0 & 1.6 & 22.6 & 75.8 \\
\hline $\begin{array}{l}\text { I read the article on CSR solely for the purpose of the } \\
\text { competition. }\end{array}$ & 1.6 & 14.5 & 32.3 & 40.3 & 11.3 \\
\hline $\begin{array}{l}\text { The competition has encouraged me to read the materials } \\
\text { related to the theory-based accounting course. }\end{array}$ & 0 & 3.2 & 12.9 & 61.3 & 22.6 \\
\hline I prefer to study alone. & 8.1 & 11.3 & 29 & 32.2 & 19.4 \\
\hline I prefer to study in a group. & 1.6 & 8.1 & 33.9 & 30.6 & 25.8 \\
\hline I prefer to do last minute work. & 0 & 4.8 & 32.3 & 37.1 & 25.8 \\
\hline $\begin{array}{l}\text { I spend a lot of time studying on the CSR topic for this } \\
\text { competition because I know this topic will be included in } \\
\text { the final examination. }\end{array}$ & 0 & 9.7 & 24.2 & 58.1 & 8 \\
\hline $\begin{array}{l}\text { I only depend on the handouts given by the lecturer in } \\
\text { completing the mind-mapping of CSR topic. }\end{array}$ & 3.2 & 21 & 30.6 & 42 & 3.2 \\
\hline $\begin{array}{l}\text { I am an ambitious person and I want to get an excellent } \\
\text { result in this course. }\end{array}$ & 0 & 0 & 6.5 & 41.9 & 51.6 \\
\hline I like calculation subject. & 0 & 0 & 4.8 & 25.8 & 69.4 \\
\hline $\begin{array}{l}\text { Completing the task given in this competition has given } \\
\text { me great satisfaction. }\end{array}$ & 0 & 0 & 9.7 & 50 & 40.3 \\
\hline $\begin{array}{l}\text { I have sufficient time to do the task given for this } \\
\text { competition. }\end{array}$ & 0 & 4.8 & 16.1 & 61.3 & 17.7 \\
\hline This competition has taught me the value of teamwork. & 0 & 0 & 3.2 & 38.7 & 58.1 \\
\hline This competition has improved my communication skills. & 0 & 4.8 & 11.3 & 51.6 & 32.3 \\
\hline $\begin{array}{l}\text { This competition has developed my problem-solving } \\
\text { skills. }\end{array}$ & 0 & 0 & 19.4 & 56.5 & 24.2 \\
\hline This competition has inculcated my reading interest. & 0 & 8.1 & 29 & 46.8 & 16.1 \\
\hline
\end{tabular}


Table 3 provides results on the factors influencing the CBL activity. In general, there were no significant differences among the factors, i.e. the number of times taking the course, family members in higher education, qualification of guardians, and MUET score with the participations in the CBL learning activity. Only gender moderately $(p=0.083)$ explained the difference in the CBL activity, which was supported by a higher mean score by the male participants (4.0435) as compared to the female's mean score (4.0292).

Table 3: Factors Influencing the CBL activity

\begin{tabular}{lcccc}
\hline & Mean & $\begin{array}{c}\text { Standard } \\
\text { deviation }\end{array}$ & $\begin{array}{c}\text { Degree of } \\
\text { freedom }\end{array}$ & Sig. \\
\hline No of times taking the course: & 4.0402 & 0.34657 & 60 & 0.412 \\
$\quad$ First time & 3.9960 & 0.29962 & & \\
$\quad$ Deferral & 4.0292 & 0.35276 & 60 & 0.083 \\
$\begin{array}{l}\text { Gender: } \\
\quad \text { Female }\end{array}$ & 4.0435 & 0.28689 & & \\
$\quad$ Male & 4.0563 & 0.34439 & 60 & 0.887 \\
$\quad \begin{array}{l}\text { Family members in higher education: } \\
\quad \text { Yes }\end{array}$ & 3.9503 & 0.30690 & & \\
$\quad$ No & 3.9355 & 0.28168 & 60 & 0.245 \\
Qualification of Guardians: & 4.1175 & 0.36177 & & \\
$\quad$ Diploma and above & & & & \\
$\quad$ SPM and below & 3.9769 & 0.33056 & 60 & 0.646 \\
MUET score: & 4.0916 & 0.33885 & & \\
$\quad$ Band 3 and below & & & & \\
$\quad$ Band 4 and above & & & & \\
$\quad$ &
\end{tabular}

This paper also intends to examine the association between CBL activity and CSR score in the final examination. Based on Table 4, there was a negative correlation between the participation in the CBL learning activity and the CSR topic examination score. This result was consistent with Margaret et al.'s work (1972), which suggests both games and rewards techniques have no effect on test performance.

Table 4: Correlation between CSR exam score and CBL

\begin{tabular}{llcc}
\hline \multicolumn{3}{c}{ Correlations } \\
\hline \multirow{3}{*}{ CSR exam } & CSR exam score & CBL \\
score & Pearson Correlation & 1 & -.014 \\
& Sig. (2-tailed) & & .914 \\
CBL & N & 62 & 62 \\
& Pearson Correlation & -.014 & 1 \\
& Sig. (2-tailed) & .914 & \\
& $\mathrm{~N}$ & 62 & 62 \\
\hline
\end{tabular}

The reasons why there is a negative correlation between the participation in the CBL learning activity and the CSR topic examination score are supported by respondents' answers on few statements. Even though the respondents realised the importance of this topic for their exam assessment, 'I spend a lot of time studying on the CSR topic for this competition because I know this topic will be included in the final examination (58.1\%, they did not 
respond accordingly as $37.1 \%$ of them agreed that they preferred to do last minute work and $48.4 \%$ agreed that they started started reading the materials required for the competition during the final week before the competition period. Besides that, $69.4 \%$ of the respondent highly agreed that they liked calculation subject and $42 \%$ of them agreed that they only depended on the handouts given by the lecturer in completing the competition.

\section{CONCLUSION}

The main objective of this paper is to examine the factors influencing the effectiveness of the Competition-based learning activity in the accounting course. From the survey, the mind mapping video competition was effective for teaching and learning as the respondents and participants had agreed in general. However, factors, such as number of times taking the course, number of family members in higher education, parents' level of academic qualification and MUET results, revealed no differences on the effectiveness of the Competition-based learning activity in the accounting course. Only gender moderately explained the difference in the CBL activity. Finally, the Corporate Social Responsibility examination score showed no correlation with the effectiveness of the Competition-based learning activity.

This study was not without any limitations as it only covered one cohort from Semester March-July 2018. Hence, making a comparison across the cohorts was beyond the boundary of possibility. The cohort in a semester's intake is heavily dependent on the production of students. It was not fully impactful to measure the effectiveness of the winning video as this learning activity solely covered the CSR topic. On that account, this video-based learning could be extended to other theory topics in the Advanced Financial Reporting II Course, such as MPERS for SMEs and MFRS for Lease. There was also no theoretical framework used in the paper to explain the factors influencing the effectiveness of the Competition-based learning activity in the accounting course. Thus, future studies may engage theories, such as the Theory of Planned Behavior or Hofstede cultural values to examine factors influencing the effectiveness of the Competition-based learning activity.

The understanding on the impact of the CBL activity can be further gauged with the possibility of conducting semi-structured or in-depth interview that includes the perspectives of behavior, group learning ability, and problem-solving skills. In relation to students' learning process, feedback from the students could also provide insights to possible CBL problems. Since the implementation of this competition was only for Advanced Financial Reporting II Course, students from different faculties and courses would have different perceptions about this video activity. Therefore, future study can be conducted by comparing between students with different courses.

The outcome from this study will help academician and students in their teaching and learning the subject matter and uploading the video on the i-Learn system and YouTube is in line with the 4.0 Industrial Revolution in higher education.

\section{REFERENCES}

Abdullah, A.M. (2011). Factors affecting business students' performance in Arab Open University: The case of Kuwait. International Journal of Business and Management 6(5): 146-155. 
Bedard, K., \& Fischer, S. (2017). Competition and academic performance: Evidence from a classroom experiment. Working papers 1704, California Polytechnic State University, Retrieved from https://ideas.repec.org/p/cpl/wpaper/1704.html.

Blazauskas, T., Limanauskiene V. \& Kersiene, V. (2012). Competition Based Online Social Learning. (Eds.): ICIST 2012, CCIS 319, 388-396.

Butler, R., \& Kedar, A. (1990). Effects of inter group competition and school philosophy on student perceptions, group processes and performance. Contemporary Educational Psychology 15: 301-308.

Burguillo, J.C. (2010). Using game theory and competition-based learning to stimulate student motivation and performance. Computers \& Education 55(2): 566-575.

Cagiltay, N.E., Ozcelik, E., \& Ozcelik, N.S. (2015). The effect of competition on learning in games. Computers \& Education 87: 35-41.

Caroll, C. (2013). Competition Based Learning in the Classroom. American Society for Engineering Education. Retrieved from: www.asee.org/public/conferences/20/papers/6233/download.

Cantador, I., \& Conde, J.M.(2010). Effects of competition in education: A case study in an e-learning environment, Retrieved from https://www.semanticscholar.org/paper/Effects-of-Competition-in-Education-\%3A-aCase-Study-C.

Chan, J.C.Y., \& Lam, S.F. (2008). Effects of competition on students' self-efficacy in vicarious learning. British Journal Educational Psychology Mar: 95-108.

Chan Lin, L.J., Hong, J.C., Horng, J.S., Chang, S.H., \& Chu, H.C. (2006). Factors influencing technology integration in teaching: a Taiwanese perspective. Innovations in Education and Teaching International 43(1): 57-68.

Chokri, B. (2012). Factors influencing the adoption of the e-learning technology in teaching and learning by students of a university class. European Scientific Journal, 8(28): 165-190.

Clifford, M.M., Cleary, A.T., \& Walster, W.G. (1972). Effects of emphasizing competition in classroom-testing procedures. The Journal of Educational Research 65(5): 234-238.

Deegan, C. (2013). Financial Accounting Theory (4 ${ }^{\text {th }}$ ed.). Australia: McGraw-Hill Education.

DiMenichi B.C., \& Tricomi, E. (2015). The power of competition: Effects of social motivation on attention, sustained physical effort, and learning. Frontiers in Psychology 6(1282): 1-13.

Fun, C.S. \& Maskat, N. (2010). Teacher-centered mind mapping vs student-centered mind mapping in the teaching of accounting at pre-U level - An action research. Procedia 
Social and Behavioral Sciences 7: 240-246.

Gajghat, R.H., Handa, C.C., \& Himte, R.L. (2017). Factors influencing academic performance of the students at university level exam: A Literature Review. International Journal of Research in Engineering and Technology 6(5). Retrieved 18 June 2019, https://ijret.org/volumes/2017v06/i05/IJRET20170605018.pdf.

Garkaz, M., Banimahd, B., \& Esmaeili, H. (2011). Factors affecting accounting students' performance: The case of students at the Islamic Azad University. Procedia Social and Behavioral Sciences 29: 122-128.

Issa, G., Hussain,S.M., \& Al-Bahadili, H. (2014). Competition-based learning: A model for the integration of competitions with project-based learning using open source LMS. International Journal of Information and Communication Technology Education (IJICTE) 10(1): 1-13.

Johnson, R. T., Johnson, D. W., \& Stanne, M. B. (1985). Effects of cooperative, competitive, and individualistic goal structures on computer-assisted instruction. Journal of Educational Psychology 77(6): 668-677.

Joseph, C., \& Rahmat, M. (2018). Exploring the perception on using the competition based learning winning video as a pedagogical tool in an accounting course. International Journal of Academic Research in Business and Social Sciences 8(2): 440-451.

Khairnar, C. M. (2015). Advance pedagogy: Innovative methods of teaching and learning. International Journal of Information and Education Technology 5(11): 869-872.

Kristensen, F., Troeng, O., Safavi, M., \& Narayanan, P. (2015). Competition in higher education - good or bad? Lund University. Retrieved from: http://portal.research.lu.se/portal/files/5680982/8519800.pdf.

Major, C.H., \& Palmer, B. (2001). Assessing the effectiveness of problem based learning in higher education: Lessons from the literature, Academic Exchange Quarterly 5(1).

Merriam Webster's Dictionary. https://www.merriam-webster.com/dictionary/competition

McParland, M., Noble, L.M., \& Livingston, G. (2004). The effectiveness of problem-based learning compared to traditional teaching in undergraduate psychiatry. Medical Education 38(8): 859-867.

Ma, V. J., \& Ma, X,. (2014). A comparative analysis of the relationship between learning styles and mathematics performance. International Journal of STEM Education 1(3): 1-13. Retrieved from http://www.stemeducationjournal.com/content/1/1/3.

Ministry of Education. (2013). Executive Summary Malaysia Education Blueprint 2015-2025 (Higher Education). Retrieved from: https://www.mohe.gov.my/en/download/awam/penerbitan/pppm-2015-2025-pt/6executivesummary-pppm-2015-2025/file.

Prince,M.J., \& Felder, R.M.(2006). Inductive teaching and learning methods: Definitions, comparisons, and research bases. Journal of Engineering Education 95(2): 123-138. 
Sukiman, S. A., Yusop, H., Mokhtar, R., \& Jaafar, N. H. (2016). Competition-Based Learning: Determining the Strongest Skill that Can Be Achieved Among Higher Education Learners. (eds.), Regional Conference on Science, Technology and Social Sciences (RCSTSS).

Veen, W. (1993). How teachers use computers in instructional practice-Four case studies in a Dutch secondary school. Computers \& Education 21: 1-8.

Zahid, M.A., Varghese, R., Mohmmed, A.M., \& Ayed, A.K. (2016). Comparison of the problem based learning-driven with traditional didactic-lecture based curricula. International Journal of Medical Education 7: 181-187.

Zakaria, Z., Kassim, A., Mohamad, A., \& Buniyamin, N. (2011). The impact of environment on engineering students' academic performance: A pilot study, 3rd International Congress Engineering Education (ICEED).

Zhang, G., Anderson, T.J., Ohland, M.W., \& Thorndyke, B.R.(2004). Identifying factors influencing engineering student graduation: A longitudinal and cross-institutional study. Journal of Engineering Education 93(4): 313-320. 